\title{
IMPLIKASI TINGKAT PROFITABILITAS TERHADAP KEPUTUSAN PEMBAGIAN SISA HASIL USAHA (SHU) PADA KOPERASI KARYAWAN KOTA TARAKAN (SUATU PENELITIAN EKSPERIMEN)
}

\author{
THE PROFITABILITY RATE IMPLICATION TO NET INCOME (SHU) \\ DISTRIBUTION DECISSION AT EMPLOYEES CO-OPERATION IN TARAKAN \\ (AN EXPERIMENT RESEARCH)
}

\author{
Mappa Panglima Banding ${ }^{1)}$, Arni $^{2)}$ \\ ${ }^{1) 2}$ Universitas Borneo Tarakan
}

\begin{abstract}
Abstrak : Penelitian ini bertujuan untuk mengidentifikasi teori atau tinjauan pustaka mengenai implikasi dari tingkat profitabilitas dengan menggunakan analisis rasio profitabilitas terhadap keputusan distribusi sisa hasil operasi pada koperasi karyawan. Jenis penelitian ini adalah eksperimen laboratorium menggunakan desain acak lengkap (CR-p) dan menggunakan desain dasar kontrol dan desain kelompok pasca-kontrol. Pengukuran berulang setiap subjek untuk semua kondisi manipulasi objek sehingga desainnya disebut desain insubject atau desain terukur berulang. Dimana peserta adalah peserta acak (peserta acak) sebanyak 10 orang berdasarkan kategori yang telah ditentukan dan dibagi menjadi dua kelompok yang menjadi manajer atau pengambil keputusan secara proporsional. Peserta dihadapkan dengan dua manipulasi pengobatan. Berdasarkan analisis data ANOVA, peneliti memperoleh hasil bahwa data yang diambil efektif. teknik analisis data yang digunakan untuk menguji hipotesis adalah Uji Berulang Berulang t menggunakan perangkat lunak SPSS 23 dengan data berupa pengisian formulir hasil simulasi membuat pembagian sisa hasil bisnis. Dan hasil pengujian diperoleh dari bentuk simulasi bahwa tingkat profitabilitas memiliki implikasi pada keputusan distribusi sisa hasil operasi.
\end{abstract}

Kata kunci: Profitabilitas, Return On Equity (ROE), Divisi keputusan dari sisa hasil operasi

Abstract : This study aims to identify the theory or literature review of the implications of the level of profitability by using profitability ratio analysis to the decision of the distribution of the remaining results of operations on employee cooperatives. This type of research is a laboratory experiment using completely randomized designs (CR-p) and using the basic design of control and post-control group designs. Repeated measurements of each subject for all conditions of manipulation of the object so that the design is called an in-subject design or repeated-measured design. Where participants are randomized participants (random participants) as many as 10 people based on predetermined categories and divided into two groups who become managers or decision makers are proportional. Participants were confronted with two treatment manipulations. Based on ANOVA data analysis, the researcher obtained the result that the data taken was effective. the data analysis technique used to test the hypothesis is Repeated Measure t Test using SPSS 23 software with data in the form of filling 
form simulation result making the division of the rest of the business results. And test results obtained from the simulation form that the level of profitability has implications on the decision of the distribution of the remaining results of operations.

\section{Keywords : Profitability, Return On Equity (ROE), Decision division of the remaining results of operations}

\section{LATAR BELAKANG}

Pertumbuhan ekonomi di indonesia tidak terlepas dari peranan koperasi terdapat banyak pihak yang memperhatikan kemampuan badan usaha dalam memenuhi tuntutan arus globalisasi. Koperasi dikelola dengan tujuan meningkatkan kesejahteraan para anggotanya dan masyarakat secara keseluruhan untuk memasuki pasar global di mana persaingan semakin sulit baik yang menyangkut persaingan kualitas produk, distribusi, dan persaingan pelayanan terhadap para pelanggan sangat membutuhkan modal yang besar yang didapatkan dari keuntungan.

Perusahaan dinamakan deviden sedangkan koperasi dinamakan sisa hasil usah (SHU).

Mayoritas anggota koperasi menginginkan SHU tiap tahun harus dibagikan. Jika SHU tidak dibagi maka anggota pun protes, meski saat itu koperasinya kekurangan modal. Bahkan, SHU pun sering dipaksakan dan dibagikan padahal koperasi merugi dan sementara SHU akan tetap dibagikan. Jika terbukti dari sisa hasil usaha yang dicadangkan terdapat sisa, maka SHU itu akan dikembalikan/dibagikan kepada para anggota sebanding dengan jasajasanya (Suhendrawati et al, 2013). Permasalahan yang akan timbul adalah bagaimana konsistensi pembagian sisa hasil usaha pada koperasi karyawan.

Koperasi sebagai badan usaha harus mensejahterahkan anggota koperasi dan menghasilkan keuntungan dari kegiatan usaha yang dilakukan dalam mengembangkan usahanya. Keuntungan dalam koperasi dikenal dengan istilah Sisa Hasil Usaha (Pariyasa et al, 2014). Mengembangkan usaha dalam koperasi tujuannya yang utama bukanlah mengejar laba, tetapi usaha yang dikelola oleh koperasi harus memperoleh SHU yang layak sehingga koperasi dapat mempertahankan kelangsungan hidupnya dan meningkatkan kemampuan usahanya.

Profitabilitas merupakan hasil akhir bersih dari berbagai kebijakan dan keputusan, dimana rasio ini digunakan sebagai alat pengukur kemampuan perusahaan memperoleh keuntungan dari setiap penjualan yang dihasilkan. Profitabilitas juga mempunyai arti penting dalam usaha mempertahankan kelangsungan hidup suatu badan usaha dalam jangka panjang, karena profitabilitas menunjukkan apakah badan usaha mempunyai prospek yang baik di masa akan datang (Mahsunah \& Hermanto, 2014). Dengan demikian, setiap badan usaha akan selalu berusaha meningkatkan profitabilitas, karena semakin tinggi tingkat profitabilitas 
suatu badan usaha maka kelangsungan hidup badan usaha atau koperasi akan terjamin.

Sisa Hasil Usaha (SHU) koperasi adalah selisih dari seluruh pemasukkan atau penerimaan tota (total revenue/TR) dengan biayabiaya atau biaya total (total cost/TC) dalam satuan buku, ditinjau dari aspek ekonomi manajerial. Sisa Hasil Usaha (SHU) yang diperoleh koperasi, selain digunakan untuk peningkatan kesejahteraan anggotanya juga digunakan untuk kelangsungan kehidupan koperasi itu sendiri. Dengan SHU yang dihasilkan, koperasi harus diperhitungkan dengan biaya yang digunakan dalam kegiatan usaha. Maka besarnya SHU yang diterima semakin besar jasa usaha, maka semakin besar SHU yang akan diterima oleh anggotanya.

Pengukuran rasio keuangan dalam profitabilitas sangat penting untuk menentukan apa yang perlu dilakukan sebagai manajemen koperasi atau pemilik koperasi dalam mengambil kebijakan atau keputusan demi perbaikan usaha di masa akan datang. Manfaat rasio keuangan adalah dapat mengetahui kekuatan atau kelemahan suatu usaha dari tahun-tahun sebelumnya dan mengetahui keadaan keuangan berada tingkat tinggi ataupun tingkat rendah (Novyanti, n.d.). Pihak manajemen atau pemilik koperasi dapat mengambil sebuah keputusan rasio keuangan yang digunakan sebagai alat ukur yang dipergunakan rasio profitabilitas. Rasio profitabilitas untuk mengukur tingkat keuntungan adalah return on asset dan return on equity (Hanum, 2012).
Profitabilitas merupakan faktor yang seharusnya mendapatkan perhatian karena untuk dapat melangsungkan hidupnya, suatu perusahaan (koperasi) harus berada dalam keadaan menguntungkan (profitable). Cara perusahaan (koperasi) untuk mendapatkan profitabilitas adalah apabila mengeluarkan dana berharap akan memperoleh kembali keuntungan melalui penjualan atau jasa yang dihasilkan. Faktor yang dipertimbangkan dalam menentukan pembagian sisa hasil usaha adalah keuntungan dan jasa usaha yang dihasilkan. Sehingga penting untuk dapat meneliti hubungan implikasi tingkat profitabilitas terhadap keputusan pembagian Sisa Hasil Usaha (SHU) pada Koperasi Karyawan Kota Tarakan.

\section{RUMUASAN MASALAH}

Adapun rumusan masalah dalam penelitian ini adalah, apakah terdapat kovarasi antara tingkat profitabilitas terhadap keputusan pembagian sisa hasil usaha pada koperasi karyawan?

\section{TUJUAN PENELITIAN}

Tujuan penelitian ini adalah ubtuk mengetahui kovarasi antara tingkat profitabilitas terhadap keputusan pembagian sisa hasil usaha pada koperasi karyawan. 


\section{TINJAUAN PUSTAKA}

Teori laba efisiensi manajerial (managerial efficiency theory of profit)

Dinyatakan bahwa suatu perusahaan dapat mencapai laba di atas normal apabila ia berhasil melakukan efisiensi pengelolaan di berbagai bidang serta dapat memenuhi keinginan konsumennya. Sesuai dengan konsep koperasi, maka koperasi akan memperoleh laba dari hasil efisiensi manajerial, karena orientasi usahanya lebih menekankan pada pelayanan usaha yang dapat memberikan manfaat dan keputusan bersama para anggotanya. Dalam Koperasi, keuntungan dari usaha yang dilakukan disebut dengan sisa hasil usaha (SHU). Jadi dapat dikatakan bahwa untuk mendapatkan sisa hasil usaha (SHU) yang maksimal, koperasi tentunya harus memaksimalkan atau mengefisienkan seluruh komponen baik keuangan maupun non keuangan (Pariyasa et al, 2014).

$\underline{\text { Kinerja keuangan }}$

Merupakan salah satu alat yang digunakan oleh pemakai laporan keuangan mengukur atau menentukkan sejauh mana kualitas perusahaan. Dari laporan keuangan perusahaan dapat diketahui keadaan finansial dan hasil-hasil yang telah dicapai perusahaan selama periode tertentu. Salah satu pengukuran profitabilitas adalah rasio keuangan yang digunakan untuk mengukur kinerja keuangan perusahaan adalah rasio profitabilitas.

\section{$\underline{\text { Profitabilitas }}$}

Adalah hasil akhir bersih dari kebijakan dan keputusan manajemen, dimana rasio ini digunakan sebagai alat pengukur kemampuan perusahaan memperoleh keuntungan dari setiap penjualan yang dihasilkan. Kebijakan dan keputusan ini menyangkut pada sumber dan penggunaan dana dalam menjalankan operasional perusahaan yang terdapat dalam laporan neraca dan laporan laba rugi (Agustina, 2013). Profitabilitas merupakan kemampuan suatu perusahaan untuk menghasilkan laba (keuntungan) dalam suatu periode tertentu. Kemampuan perusahaan (koperasi) untuk menghasilkan laba akan dapat menarik para investor untuk menanamkan dananya guna memperluas usahanya, sebaliknya tingkat profitabilitas yang rendah akan menyebabkan para investor menarik dananya (Mahsunah \& Hermanto, 2014).

\section{$\underline{\text { Sisa Hasil Usaha (SHU) }}$}

Adalah pendapatan koperasi yang diperoleh dalam satu tahun buku dikurang dengan biaya, penyusutan, dan kewajiban lain termasuk pajak dalam tahunan buku yang bersangkutan menurut UU Koperasi No.25 Tahun 1992. SHU setelah dikurangi dana cadangan, dibagikan kepada anggota sebanding jasa usaha yang dilakukan oleh masing-masing anggota dengan koperasi, serta digunakan untuk keperluan pendidikan perkoperasian dan keperluan koperasi, sesuai dengan keputusan Rapat Anggota Tahunan (Sitio \& Tamba, 2001). 


\section{$\underline{\text { Pembagian SHU }}$}

Pembagian dilakukan secara adil sebanding dengan besarnya jasa usaha masing-masing anggota. Untuk koperasi indonesia, dasar hukumnya adalah pasal 5 ayat 1 ; UU No.25 Tahun 1992 tentang perkoperasian mengatakan bahwa pembagian SHU kepada anggota dilakukan tidak berdasarkan modal yang dimiliki seseorang dalam koperasi, tetapi berdasarkan perimbangan jasa usaha anggota terhadap koperasi. Dalam penjelasannya disebutkan bahwa pembagian SHU berdasarkan jasa usaha masing-masing anggota. Yang dimaksud dengan jasa usaha adalah transaksi usaha dan partisipan modal. Besarnya penetapan pembagian kepada anggota dan jenis serta besarnya keperluan lain, ditetapkan oleh Rapat Anggota Tahunan (RAT).

Perhitungan Pembagian Sisa Hasil $\underline{\text { Usaha, }}$

Menurut (Winarko, 2014), Pendapatan koperasi yang tidak ada lain adalah penerimaan koperasi atas kontribusi anggota koperasi bagi pengeluaran biaya-biaya operasional koperasi, dipergunakan oleh koperasi untuk membayar segala pengeluaran koperasi dalam rangka memutar roda organisasi koperasi agar mampu mencapai tujuannya. Tugas pengurus adalah menggunakan pendapatan koperasi seefisien mungkin dengan hasil yang optimal. Perhitungan akhir tahun yang menggambarkan penerimaan pendapatan koperasi dan alokasi penggunaannya untuk biayabiaya koperasi pasal 45 ayat (1) UU
No. 25/1992 dapat dirumuskan sebagai berikut :

Sisa Hasil Usaha = Pendapatan (Biaya + Penyusutan + Kewajiban Lain + Pajak)

\section{METODE PENELITIAN}

\section{Desain Eksperimen}

Penelitian ini merupakan jenis eksperimen tulen dengan desain yang digunakan dalam eksperimen ini adalah posttest control group design dengan Completely Randomized-within-subject Designs disingkat dengan CR-p yaitu penelitian eksperimen yang membandingkan dua kelompok yang diberi perlakuan yang berbeda (Campbell \& Stanley, 1963; Ghozali, 2008).

Untuk menguji hipotesis dengan menggunakan Completely Randomized-within-subject Designs, dari dua manipulasi atau perlakuan dilakukan percobaan 1x2 antara partisipan dengan melihat tingkat profitabilitas melalui laporan keuangan koperasi yaitu profitabilitas baik dan profitabilitas buruk.

Model matematis eksperimen dengan menggunakan Completely Randomized-within-subject Designs, dapat dituliskan sebagai berikut :

Yij $=\mu+\alpha j+\varepsilon i \quad(j) \quad(i=$ $1, \ldots \ldots \ldots \ldots \ldots \ldots . . n ; j=1, \ldots \ldots \ldots \ldots . ., p)$

Dimana :

Yij : pengaruh profitabilitas ke-i dengan treatmen level aj

$\mu$ : grand mean dari 2 grup mean keputusan pembagian $\mathrm{SHU}$

$\alpha \mathrm{j}:$ pengaruh treatmen untuk populasi $\alpha \mathrm{j}$ dan besarnya sama 
dengan $\mu \mathrm{j}-\mu$, mencerminkan pengaruh profitabilitas $\alpha j$

cij : pengaruh kesalahan whithin group yang berhubungan dengan Yij dan sama dengan Yij- $\mu-\alpha j$. Hal ini mencerminkan semua pengaruh yang dapat dikaitkan dengan level $\alpha j$

Dengan desain CR-p maka hipotesis yang dapat diuji adalah sebagai berikut:

H0 : $\mu 1 .=(\mu 1=\mu 2)=0$ (tidak ada perbedaan rata-rata profitabilitas)

Ha $\quad: \mu 1-\mu 2 \neq 0$ (ada perbedaan rata-rata profitabilitas)

Dengan kriteria tingkat profitabilitas:

1. Jika angka Sig $\geq 0.05 \mathrm{H} 0$ diterima maka Ha ditolak, yang berarti tidak ada dampak antara profitabilitas terhadap keputusan pembagian SHU

2. Jika angka Sig $<0.05$ H0 ditolak maka Ha diterima, yang berarti ada dampak antara profitabilitas terhadap keputusan pembagian SHU

\section{$\underline{\text { Partisipan }}$}

Yang menjadi partisipan dalam penelitian ini adalah manajer atau pendidikan S2 sebagai pengambil keputusan organisasi atau koperasi yang memperoleh lebih dari satu kali manipulasi dari objek yang diteliti, artinya terjadi pengukuran berulang masing-masing subjek untuk semua kondisi manipulasi terhadap objek. Dimana jumlah partisipan ini berjumlah 10 orang dengan 2 perlakuan manipulasi maka kemudian menjadi 2 kelompok secara acak yang masing-masing beranggotakan 5 partisipan. Sehingga baik kelompok subjek termanipulasi maupun kelompok subjek pembanding dalam eksperimen ini adalah seluruh subjek atau partisipan eksperimen atau partisipan yang mendapatkan manipulasi yang sama.

\section{$\underline{\text { Manipulasi }}$}

Dalam eksperimen ini partisipan diminta untuk menjadi manajer untuk memberikan keputusan pembagian sisa hasil usaha dalam 2 kondisi perlakuan yang berbeda.

1. Dalam kondisi perlakuan pertama, partisipan akan menerima laporan keuangan dan diminta untuk melihat informasi laporan keuangan melalui profitabilitas yang baik.

2. Dalam kondisi perlakuan pertama, partisipan akan menerima laporan

3. keuangan dan diminta untuk melihat informasi laporan keuangan melalui profitabilitas yang buruk.

\section{HASIL PENELITIAN}

Uji manipulasi dilakukan 2 kali pengujian dengan tujuan untuk mendapatkan perangkat simulasi yang sesuai dengan tujuan eksperimen. Uji manipulasi pertama dilakukan mulai dari tanggal $12-18$ April 2018 secara online dengan partisipan 10 orang, kemudian uji manipulasi kedua dilakukan dari tanggal 20 April - 14 Mei 2018 secara online dan offline partisipan 10 orang mendatangi organisasi/instansi-instansi yang ada di kota tarakan. Data manipulasi yang sudah dikumpulkan kemudian 
diolah dengan menggunakan SPSS versi 23 dengan hasil.

Eksperimen dilakukan 1 kali pengujian, penelitian ini secara keselurahan eksperimen melibatkan 10 partisipan atau subjek dari berbagai BUMN/BUMD, perusahaan swasta lainnya dan pendidikan tinggi. Dimana pengumpulan partisipan dilakukan dari tanggal 25 Mei - 6 Juni 2018 yang dilakukan secara online dan offline dengan peserta 10 orang. Dalam eksperimen untuk menguji hipotesis menggunakan desain Completely Randomized (Repeated Measures t Test) memberikan dua jenis pengungkapan profitabilitas guna memperoleh suatu kesimpulan, untuk menganalisis uji hipotesis yang menggunakan desain Completely Randomized dengan dua perlakuan (treatment) memberikan dua jenis pengungkapan yaitu profitabilitas baik dan profitabilitas buruk secara random kepada partisipan (Ghozali, 2008). Menganalisis data menggunakan teknik Repeated Measures $\mathrm{t}$ Test pada perlakukan (treatment) dalam penelitian ini menggunakan bantuan aplikasi perhitungan SPSS 23 dengan taraf signifikansi $<0.05$.

Hasil paired samples statistics dan samples test menunjukkan bahwa pemberian keputusan pembagian sisa hasil usaha pada manipulasi pertama partisipan menerima laporan keuangan koperasi dengan melihat analisis rasio profitabilitas (ROE), profitabilitas yang buruk sebesar 5.20 (mean $=5.20, \mathrm{SD}=1.55)$ sedangkan profitabilitas yang baik sebesar 3.50 (mean $=3.50, \mathrm{SD}=$ 1.95). Dari analisis diatas terdapat perbedaan nilai rata-rata sebesar 1.70 dan apakah perbedaan ini signifikansi, secara statistik dapat dilihat pada nilai $\mathrm{t}$ sebesar 3.157 dengan probabilitas 0.012. Karena probabilitas dibawah 0.05 maka hipotesis nol ditolak dan hipotesis alternatif diterima yang berarti bahwa ada perbedaan nilai terhadap profitabilitas yang buruk dengan profitabilitas yang baik. Setelah menerima laporan profitabilitas yang buruk nilai rata-rata dari 5.20 menjadi 3.20 yang berarti profitabilitas berdampak terhadap keputusan pembagian sisa hasil usaha karena nilai sig $=0.012<0.05$ maka Ho ditolak yang berarti bahwa ada dampak pengungkap profitabilitas yang baik dan profitabilitas buruk terhadap keputusan pembagian sisa hasil usaha.

\section{PEMBAHASAN}

Profitabilitas adalah hasil akhir bersih dari kebijakan dan keputusan manajemen, dimana rasio ini digunakan sebagai alat pengukur kemampuan perusahaan memperoleh keuntungan dari setiap penjualan yang dihasilkan. Tingkat profitabilitas koperasi yang tinggi membantu koperasi untuk dapat membiayai usaha mereka menggunakan modal sendiri. Tingkat profitabilitas koperasi dapat dilihat dari perbandingan antara sisa hasil usaha dengan modal koperasi tersebut. Ketika koperasi memiliki profitabilitas yang tinggi, maka koperasi akan cenderung menggunakan pendanaan internal untuk membiayai kegiatan usaha mereka dari pada menggunakan 
pendanaan eksternal. Oleh karena itu profitabilitas diprediksikan memiliki pengaruh positif terhadap modal sendiri koperasi (Nafisa, 2015). Dari hasil penelitian ini didukung penelitian (Wahyunita \& Suryono, 2014) menyatakan bahwa modal sendiri memiliki pengaruh dominan terhadap sisa hasil usaha.

Hasil penelitian yang dilakukan memberikan pengetahuan implikasi tingkat profitabilitas terhadap keputusan pembagian sisa hasil usaha pada koperasi karyawan kota tarakan dengan menggunakan 2 perlakuan terhadap laporan keuangan dan analisis rasio profitabilitas (ROE). Berdasarkan hasil pengujian hipotesis alternatif diterima menyatakan bahwa tingkat profitabilitas berdampak terhadap keputusan pembagian sisa hasil usaha. Hasil menunjukkan bahwa rata-rata partisipan akan melakukan keputusan pembagian sisa hasil usaha dengan mendapatkan laba yang lebih besar pada tingkat profitabilitas yang baik, maka keputusan pembagian sisa hasil usaha akan lebih tinggi sesuai dengan laba yang diperoleh dalam setiap tahunnya. Hipotesis diuji dengan teknik Repeated Measure $t$ Test atau Paired sample t Test adalah uji yang digunakan untuk 2 perlakuan yang berpasangan dengan variabel independen secara berulang.

Berdasarkan hasil hipotesis diuji Repeated Measure $t$ Test atau Paired sample $t$ Test menunjukkan $\mathrm{Ha}$ diterima bahwa tingkat profitabilitas berdampak terhadap keputusan pembagian sisa hasil usaha pada koperasi karyawan. Sehingga dapat dinyatakan bahwa pada tingkat kepercayaan partisipan
95\% ada dampak terhadap tingkat profitabiltas terhadap keputusan pembagian sisa hasil usaha yang melalui 2 perlakuan yang baik dan buruk dengan laporan keuangan dan analisis rasio profitabilitas (ROE).

\section{KESIMPULAN DAN SARAN}

$\underline{\text { Kesimpulan }}$

Berdasarkan fenomena, rumusan masalah, metode penelitian dan hasil penelitian, maka peneliti menarik kesimpulan bahwa pembahasan secara empiris bahwa terdapat kovarasi antara tingkat profitabilitas terhadap keputusan pembagian sisa hasil usaha pada koperasi karyawan. Yang artinya pengungkapan tingkat profitabilitas terhadap keputusan pembagian sisa hasil usaha pada koperasi karyawan.

$\underline{\text { Saran }}$

Adapun saran terkait penelitian ini adalah bisa menjadi referensi dalam hal keputusan pembagian sisa hasil usaha pada pada organisasi koperasi khususnya koperasi karyawan

\section{DAFTAR PUSTAKA}

Agustina, S. 2013. Pengaruh Profitabilitas dan Pengungkapan Corporate Social Responsibility Terhadap Nilai Perusahaan (Studi Empiris pada Perusahaan Manufaktur yang Terdaftar di Bursa Efek Indonesia). Jurnal, vol 1, 123. 
Anwar, S. 2010. Ekonomi Koperasi. (A. Juliana, Ed.). Tarakan: Fakultas Ekonomi Universitas Borneo.

Dewik, N. K. S., \& Jember, I. M. 2016. Faktor-Faktor Yang Mempengaruhi Sisa Hasil Usaha (Shu) Koperasi Simpan Pinjam (Ksp) Di Kecamatan Kuta Utara Kabupaten Badung. E-Jurnal Ekonomi Pembangunan Universitas Udayana, 5(7), 729-753.

Ghozali, I. 2008. Desain Penelitian Eksperimental. Semarang: Universitas Diponegoro.

Handoko, J. 2012. Jurnal ilmiah mahasiswa akuntansi. Jurnal Ilmiah Mahasiswa Akuntansi, 1(3).

Hanum, Z. 2012. Pengaruh Profitabilitas Terhadap Modal Kerja Pada Perusahaan Makanan Dan Minuman Yang Terdaftar Di Bursa Efek Indonesia. Jurnal Manajemen \& Bisnis, 11, 15.

Kasmir. 2010. Analisis laporan keuangan. Jakarta: Rajawali Pers

Kinney, W. R. 1986. Empirical Accounting Research Design For Ph.D. Students. The Accounting Review, LXI(2), 338-350.

Leunupun, P. 2003. Protabilitas Ekuitas dan Beberapa Faktor yang Mempengaruhinya. Jurnal Akuntansi \& Keuangan, 5.

Mahsunah, T., \& Hermanto, S. B. 2014. Pengaruh Free Cash Flow dan Kepemilikan Institusional terhadap Kebijakan Hutang dan Nilai
Perusahaan. Ilmu \& Riset Akuntansi, 3(4), 1-17.

Marakas, George M: O'Brien, J. A. 2013. Introduction to Information Systems. (B. Gordon, Ed.) (16th ed.). New York: McGraw_Hill, Irwin.

Martono, C. 2002. Intensitas Modal Tertimbang Serta Perusahaan Manufaktur Yang Go- Public. Jurnal Akuntansi \& Keuangan, 4(2), 126-140.

Nafisa, T. 2015. Faktor-faktor yang mempengaruhi modal sendiri pada koperasi.

Nahartyo, E. 2013. Desain dan Implementasi Riset Eksperimen (2nd ed.). Yogyakarta: UPP STIM YKPN.

Nahartyo, E., \& Utami, I. 2016. Paduan Praktis Riset Eksperimen (1st ed.). Jakarta: Indeks.

Novyanti. (n.d.). Sisa Hasil Usaha (SHU) Pada Koperasi Bina Utama Jaya.

Pariyasa et al. 2014. Pengaruh Modal, Volume Dan Anggota Terhadap Sisa Hasil Usaha Pada Koperasi Serba Usaha Kecamatan Buleleng, 4(1).

Shadish, W. R., Cook, T. D., \& Campbell, D. T. 2002. Experimental and QuasiExperimental Designs for Generalized Causal Inference (Vol. 100). Boston: Houghton Mifflien Company.

Sitio, A. \& Tamba, H. 2001. Koperasi : Teori dan Praktek. (Wisnu Chandra Kristiaji, Ed.). Jakarta.

Sugiyono. 2007. Metode Penelitian Administrasi. Bandung: Alfabeta. 
Suhendrawati et al. 2013.

Konsistensi Pembagian Sisa

Hasil Usaha ( SHU ) Pada

Koperasi Pegawai Republik

Indonesia (KP-RI)

Universitas Jember (The

Consistency Of Net Income

Distribution To Indonesia

Republik Coorporation

Employes At University

Jember). Artikel Ilmiah Hasil

Penelitian Mahasiswa, 1-7.

Umi, S. 2006. Metodologi

Kuantitatif. Jakarta: Salemba Empat.

Umi, S. 2010. Research Methods for

Business. Jakarta: Salemba

Empat.

Wahyunita, R., \& Suryono, B. 2014.

Pengaruh modal sendiri dan

kinerja keuangan terhadap sisa hasil usaha, 3(8).

Winarko, S. P. 2014. Pengaruh Modal Sendiri, Jumlah Anggota Dan Aset Terhadap Sisa Hasil Usaha Pada Koperasi Di Kota Kediri. Nusantara of Research, 1(2), 151-167.

Yunawati, S., \& Gusweni, A. 2012. Faktor Yang Mempengaruhi Profitabilitas Pada Koperasi Pegawai Republik Indonesia (Kpri) Di Kecamatan Rambah Kabupaten Rokan Hulu 2008-2012, 4, 1-17. 